\title{
Effects of Heme Electronic Structure and Local Heme Environment on Catalytic Activity of a Peroxidase- Mimicking Heme-DNAzyme
}

Shota Hagiwara, ${ }^{1}$ Atsuya Momotake, ${ }^{1}$ Takashi Ogura,${ }^{2}$ Sachiko Yanagisawa, ${ }^{3}$ Akihiro Suzuki, ${ }^{4}$ Saburo Neya, ${ }^{5}$ and Yasuhiko Yamamoto, ${ }^{1,6, *}$

${ }^{1}$ Department of Chemistry, University of Tsukuba, Tsukuba 305-8571, Japan ${ }^{2}$ Department of Life Science, Graduate School of Life Science, University of Hyogo, Ako-gun, Hyogo 678-1297, Japan

${ }^{3}$ Department of Life Science, Graduate School of Science, University of Hyogo, Ako-gun, Hyogo 678-1297, Japan

${ }^{4}$ Department of Material Engineering, National Institute of Technology,

Nagaoka College, Nagaoka 940-8532, Japan

${ }^{5}$ Department of Physical Chemistry, Graduate School of Pharmaceutical Sciences, Chiba University, Chuoh-Inohana, Chiba 260-8675, Japan

${ }^{6}$ Tsukuba Research Center for Energy Materials Science (TREMS),

University of Tsukuba, Tsukuba 305-8571, Japan

* Corresponding author: Yasuhiko Yamamoto

Phone/Fax: +81-29-853-6521, E-mail: yamamoto@chem.tsukuba.ac.jp 


\section{Contents}

\section{Contents}

Figure S1. Soret absorption of a parallel G-quadruplex DNA of $6 \mathrm{mer} / \mathrm{T}$ titrated against $3,8-\mathrm{DMD}\left(\mathrm{Fe}^{3+}\right)(\mathrm{A})$, and that of $6 \mathrm{mer} / \mathrm{T}(\mathrm{B})$ and $6 \mathrm{mer} / \mathrm{A}(\mathrm{C})$ titrated against $2,8-\mathrm{DPF}\left(\mathrm{Fe}^{3+}\right)$ in $300 \mathrm{mM} \mathrm{KCl}$ and $50 \mathrm{mM}$ potassium phosphate buffer, $\mathrm{pH} 6.80$, together with $0.08 \mathrm{w} / \mathrm{v} \%$ Triton $\mathrm{X}-100$ and $0.5 \mathrm{v} / \mathrm{v} \%$ dimethyl sulfoxide, at $25{ }^{\circ} \mathrm{C}$.

Figure S2. Soret absorption of a parallel G-quadruplex of 6mer titrated against $\operatorname{Proto}\left(\mathrm{Fe}^{3+}\right)(\mathrm{A})$ and $2,8-\mathrm{DPF}\left(\mathrm{Fe}^{3+}\right)$ (B) in $300 \mathrm{mM} \mathrm{KCl}$ and $50 \mathrm{mM}$ potassium phosphate buffer, $\mathrm{pH} 6.80$, together with $0.08 \mathrm{w} / \mathrm{v} \%$ Triton $\mathrm{X}$ 100 and $0.5 \mathrm{v} / \mathrm{v} \%$ dimethyl sulfoxide, at $25^{\circ} \mathrm{C}$.

Figure S3. Visible resonance Raman spectra of the $\mathrm{CO}$ adducts of the Proto $\left(\mathrm{Fe}^{2+}\right)$ 6mer (bottom), Proto $\left(\mathrm{Fe}^{2+}\right)-6 \mathrm{mer} / \mathrm{T}$ (middle), and Proto $\left(\mathrm{Fe}^{2+}\right)-6 \mathrm{mer} / \mathrm{A}$ complexes (top) at $25{ }^{\circ} \mathrm{C}$. Residual error (the difference between the experimental and theoretical values) (A), observed (red) and simulated (blue) $v_{\mathrm{CO}}$ bands (B), and simulated individual bands (C).

Figure S4. Visible resonance Raman spectra of the $\mathrm{CO}$ adducts of the Proto $\left(\mathrm{Fe}^{2+}\right)$ 6mer (bottom), Proto $\left(\mathrm{Fe}^{2+}\right)-6 \mathrm{mer} / \mathrm{T}$ (middle), and Proto $\left(\mathrm{Fe}^{2+}\right)-6 \mathrm{mer} / \mathrm{A}$ complexes (top) at $25{ }^{\circ} \mathrm{C}$. Residual error (the difference between the experimental and theoretical values) (A), observed (red) and simulated (blue) $v_{\mathrm{Fe}-\mathrm{O}}$ bands $(\mathrm{B})$, and simulated individual bands $(\mathrm{C})$.

Figure S5. $\mathrm{pH}$ dependence of Soret absorption of the 3,8-DMD $\left(\mathrm{Fe}^{3+}\right)-6 \mathrm{mer} / \mathrm{T}(\mathrm{A})$, 3,8-DMD $\left(\mathrm{Fe}^{3+}\right)-6 \mathrm{mer} / \mathrm{A}$ (B), 2,8-DPF $\left(\mathrm{Fe}^{3+}\right)-6 \mathrm{mer} / \mathrm{T}$ (C), and 2,8$\mathrm{DPF}\left(\mathrm{Fe}^{3+}\right)-6 \mathrm{mer} / \mathrm{A}$ complexes (D) in $300 \mathrm{mM} \mathrm{KCl}$ and $50 \mathrm{mM}$ potassium phosphate buffer at $25^{\circ} \mathrm{C}$.

Figure S6. $\quad \mathrm{pH}$ dependence of Soret absorption of the Proto $\left(\mathrm{Fe}^{3+}\right)-6$ mer (A), and Proto $\left(\mathrm{Fe}^{3+}\right)-6 \mathrm{mer} / \mathrm{T}$ (B) complexes in $300 \mathrm{mM} \mathrm{KCl}$ and $50 \mathrm{mM}$ potassium phosphate buffer at $25^{\circ} \mathrm{C}$.

Figure S7. Schematic representation of the structure of the $1: 2$ heme $\left(\mathrm{Fe}^{3+}\right)-6$ mer complex. Heme $\left(\mathrm{Fe}^{3+}\right)$ is sandwiched between the 3'-terminal G-quartets of 6 mers. 


\section{3,8-DMD-6mer/T Complex}
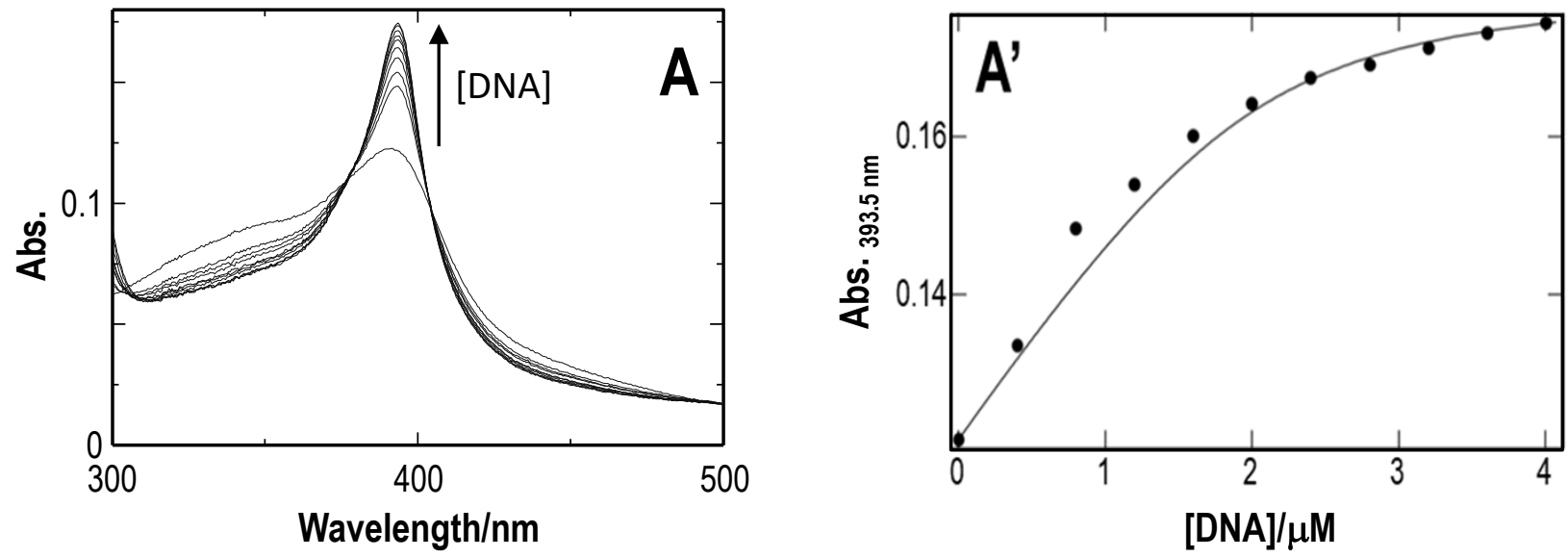

\section{2,8-DPF-6mer/T Complex}
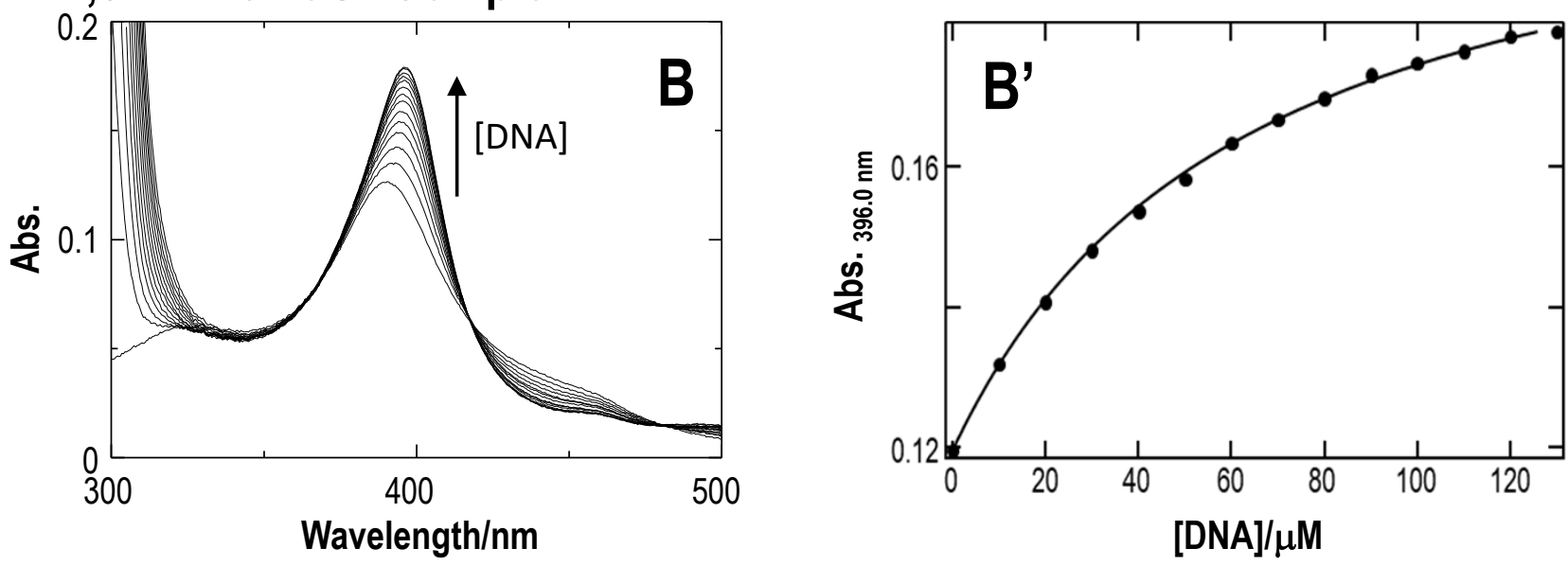

\section{2,8-DPF-6mer/A Complex}
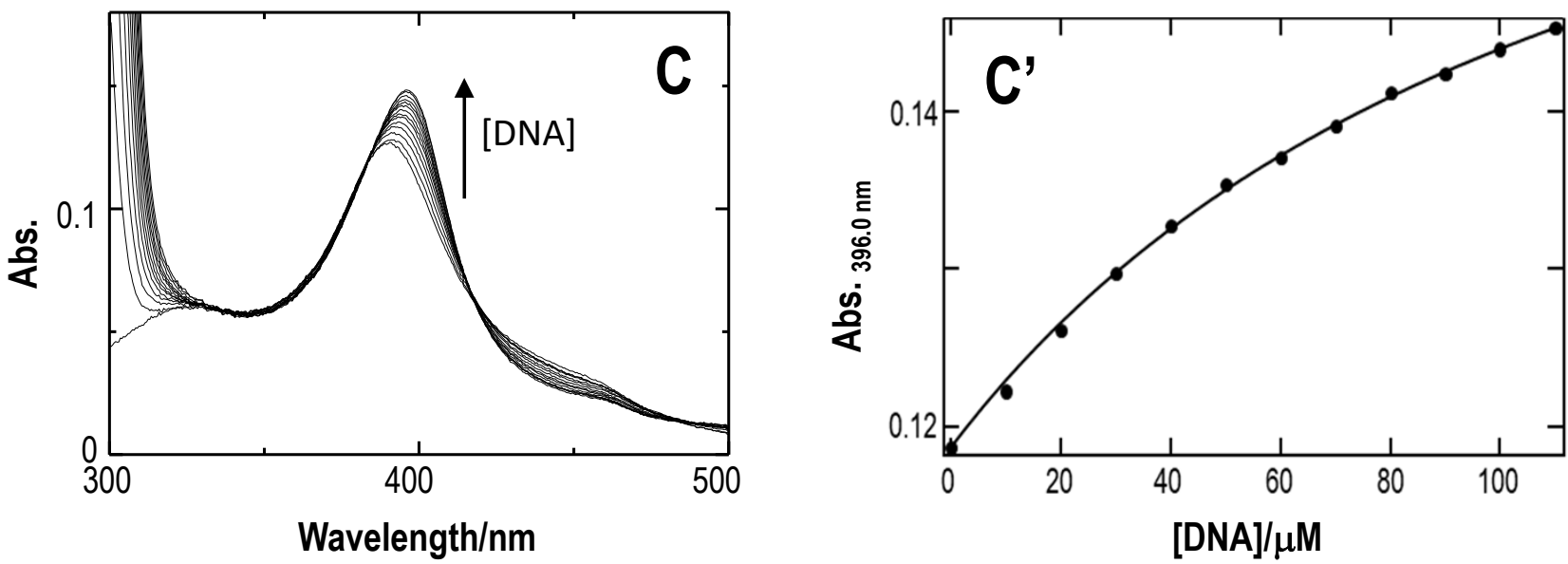

Figure S1. Soret absorption, 300-500 nm, of a parallel G-quadruplex DNA of $6 \mathrm{mer} / \mathrm{T}, 0-60 \mu \mathrm{M}$, titrated against $2.0 \mu \mathrm{M} 3,8-\mathrm{DMD}\left(\mathrm{Fe}^{3+}\right)(\mathrm{A})$, and that of $6 \mathrm{mer} / \mathrm{T}(\mathrm{B})$ and $6 \mathrm{mer} / \mathrm{A}(\mathrm{C}), 0-130 \mu \mathrm{M}$, titrated against $2.0 \mu \mathrm{M} 2,8-\mathrm{DPF}\left(\mathrm{Fe}^{3+}\right)$ in $300 \mathrm{mM} \mathrm{KCl}$ and $50 \mathrm{mM}$ potassium phosphate buffer, $\mathrm{pH} 6.80$, together with 0.08 $\mathrm{w} / \mathrm{v} \%$ Triton X-100 and $0.5 \mathrm{v} / \mathrm{v} \%$ dimethyl sulfoxide, at $25^{\circ} \mathrm{C}$. Heme binding constants $\left(K_{\mathrm{a}} \mathrm{s}\right)$ of $4.3 \pm 1.0$, $0.016 \pm 0.001$, and $0.0084 \pm 0.0004 \mu \mathrm{M}^{-1}$ were obtained for the $3,8-\mathrm{DMD}\left(\mathrm{Fe}^{3+}\right)-6 \mathrm{mer} / \mathrm{T}\left(\mathrm{A}^{\prime}\right), 2,8-$ $\mathrm{DPF}\left(\mathrm{Fe}^{3+}\right)-6 \mathrm{mer} / \mathrm{T}\left(\mathrm{B}^{\prime}\right)$, and 2,8-DPF( $\left.\mathrm{Fe}^{3+}\right)-6 \mathrm{mer} / \mathrm{A}$ complexes $\left(\mathrm{C}^{\prime}\right)$, respectively. 


\section{Proto-6mer Complex}
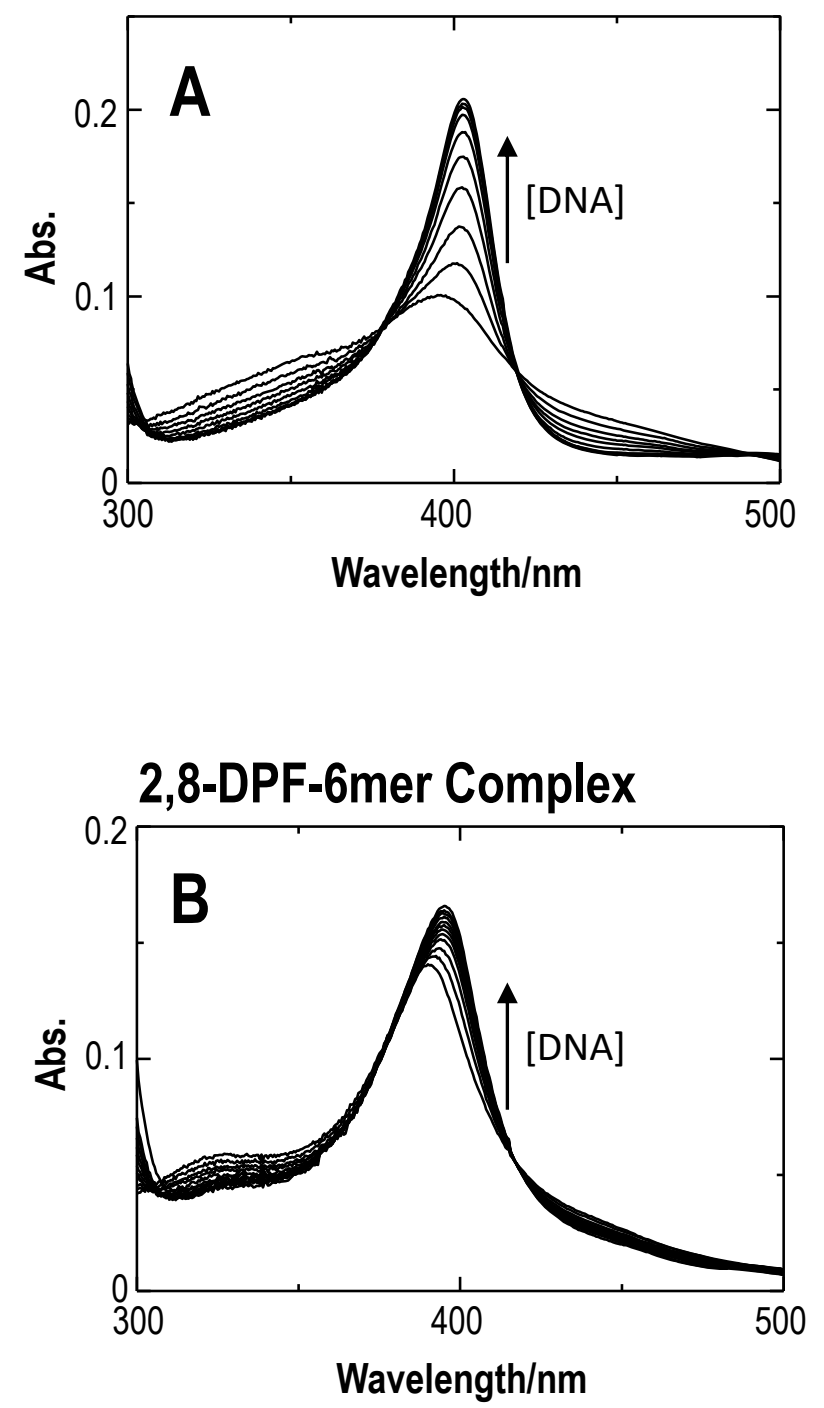
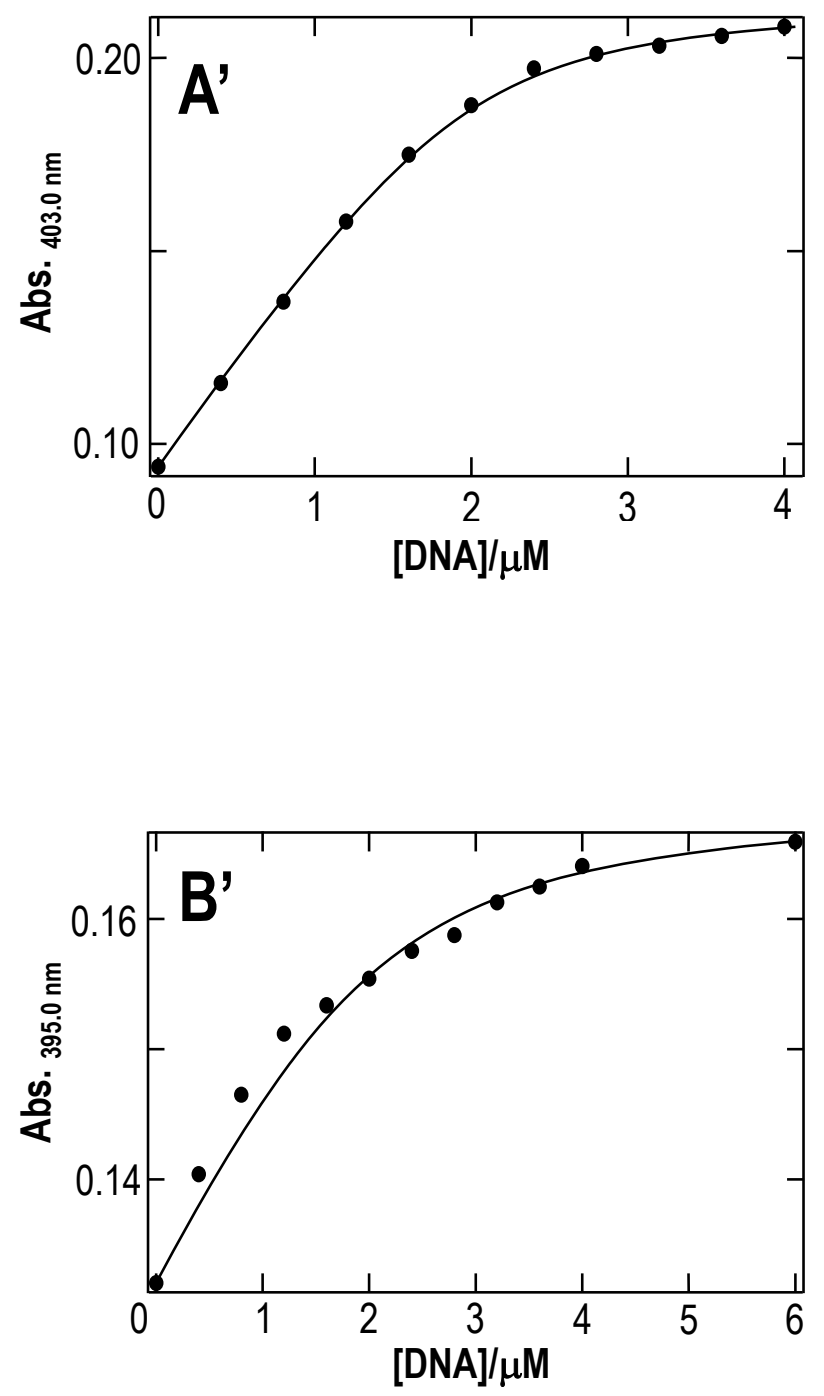

Figure S2. Soret absorption, 300-500 nm, of a parallel G-quadruplex of $6 \mathrm{mer}, 0-6 \mu \mathrm{M}$, titrated against $2.0 \mu \mathrm{M}$ Proto $\left(\mathrm{Fe}^{3+}\right)(\mathrm{A})$ and $2,8-\mathrm{DPF}\left(\mathrm{Fe}^{3+}\right)(\mathrm{B})$ in $300 \mathrm{mM} \mathrm{KCl}$ and 50 $\mathrm{mM}$ potassium phosphate buffer, $\mathrm{pH} 6.80$, together with $0.08 \mathrm{w} / \mathrm{v} \%$ Triton $\mathrm{X}-100$ and $0.5 \mathrm{v} / \mathrm{v} \%$ dimethyl sulfoxide, at $25{ }^{\circ} \mathrm{C}$. Heme binding constants $\left(K_{\mathrm{a}} \mathrm{s}\right)$ of $6.5 \pm 0.7$ and $2.3 \pm 0.3 \mu \mathrm{M}^{-1}$ were obtained for the Proto($\left(\mathrm{Fe}^{3+}\right)$-6mer (A') and 2,8-DPF( $\left(\mathrm{Fe}^{3+}\right)-6 \mathrm{mer}$ complexes (B'), respectively. 

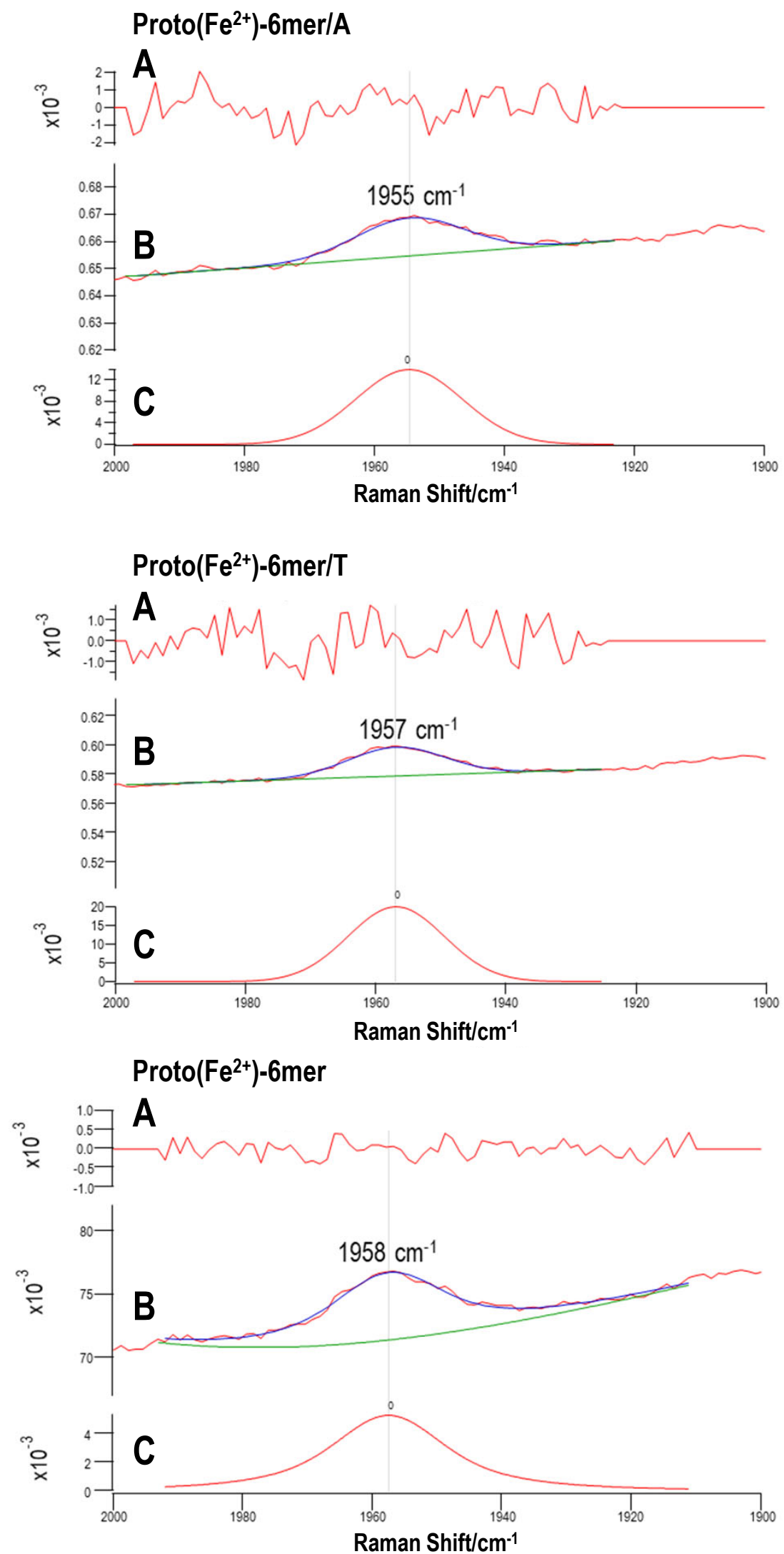

Figure S3. Visible resonance Raman spectra of the $\mathrm{CO}$ adducts of the Proto( $\left.\mathrm{Fe}^{2+}\right)-6$ mer (bottom), Proto( $\left.\mathrm{Fe}^{2+}\right)-6 \mathrm{mer} / \mathrm{T}$ (middle), and Proto $\left(\mathrm{Fe}^{2+}\right)$-6mer/A complexes (top) at $25{ }^{\circ} \mathrm{C}$. Residual error (the difference between the experimental and theoretical values) (A), observed (red) and simulated (blue) $v_{\mathrm{CO}}$ bands (B), and simulated individual bands (C). The green line in (B) indicates the baseline. The wavenumber of the band denoted as 0 has been considered and discussed in the manuscript. Samples were prepared by mixing $20 \mu \mathrm{M}$ Proto $\left(\mathrm{Fe}^{2+}\right)$ and $40 \mu \mathrm{M}$ G-quadruplex DNA in $50 \mathrm{mM}$ potassium phosphate buffer, $\mathrm{pH} 6.80$, and $300 \mathrm{mM} \mathrm{KCl}$. 

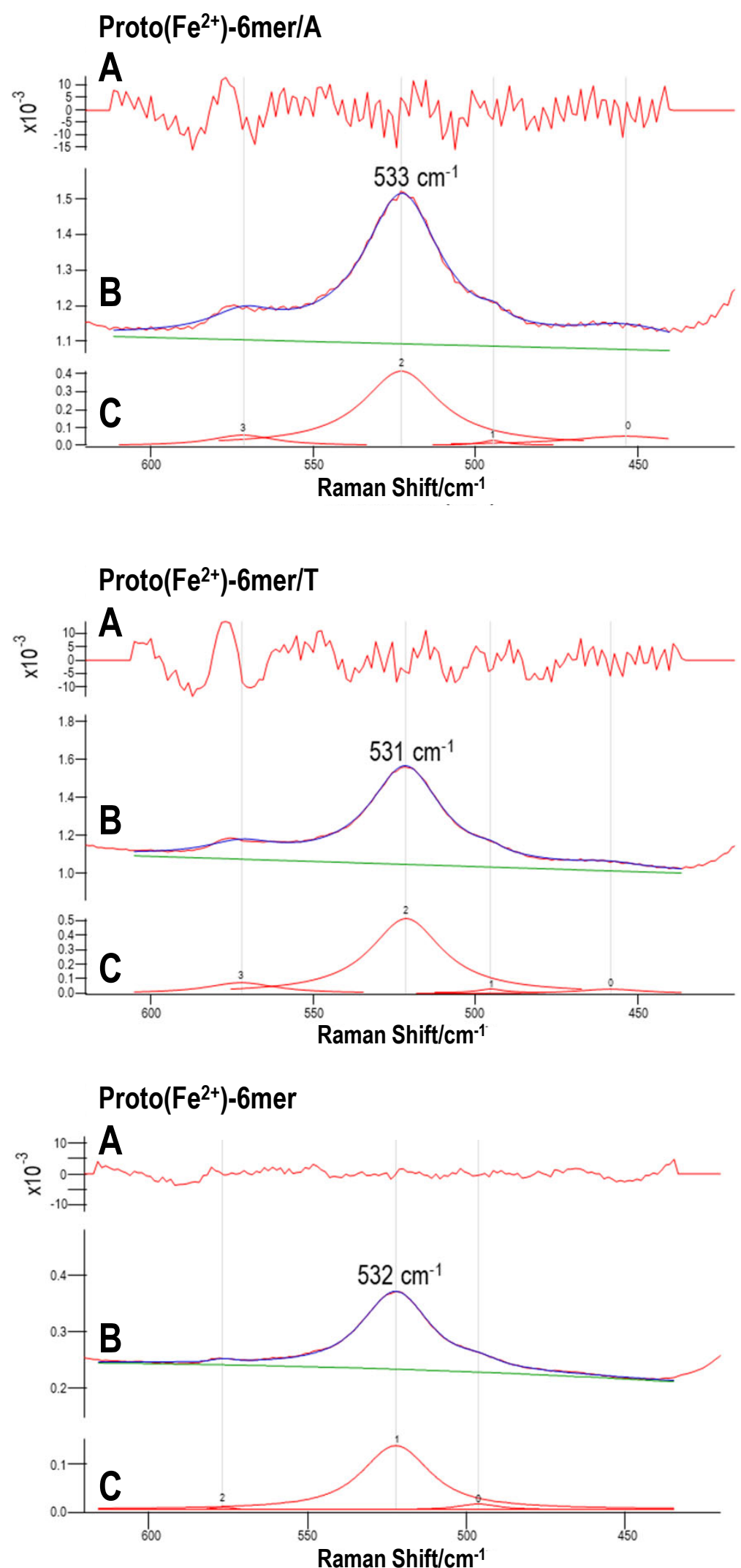

Figure S4. Visible resonance Raman spectra of the $\mathrm{CO}$ adducts of the Proto $\left(\mathrm{Fe}^{2+}\right)-6$ mer (bottom), Proto $\left(\mathrm{Fe}^{2+}\right)-6 \mathrm{mer} / \mathrm{T}$ (middle), and Proto $\left(\mathrm{Fe}^{2+}\right)$-6mer/A complexes (top) at $25{ }^{\circ} \mathrm{C}$. Residual error (the difference between the experimental and theoretical values) (A), observed (red) and simulated (blue) $v_{\mathrm{Fe}-\mathrm{O}}$ bands (B), and simulated individual bands (C). The green line in (B) indicates the baseline. The wavenumber of the band denoted as 0 has been considered and discussed in the manuscript. Samples were prepared by mixing $20 \mu \mathrm{M}$ Proto $\left(\mathrm{Fe}^{2+}\right)$ and $40 \mu \mathrm{M}$ G-quadruplex DNA in $50 \mathrm{mM}$ potassium phosphate buffer, $\mathrm{pH} 6.80$, and $300 \mathrm{mM} \mathrm{KCl}$. 

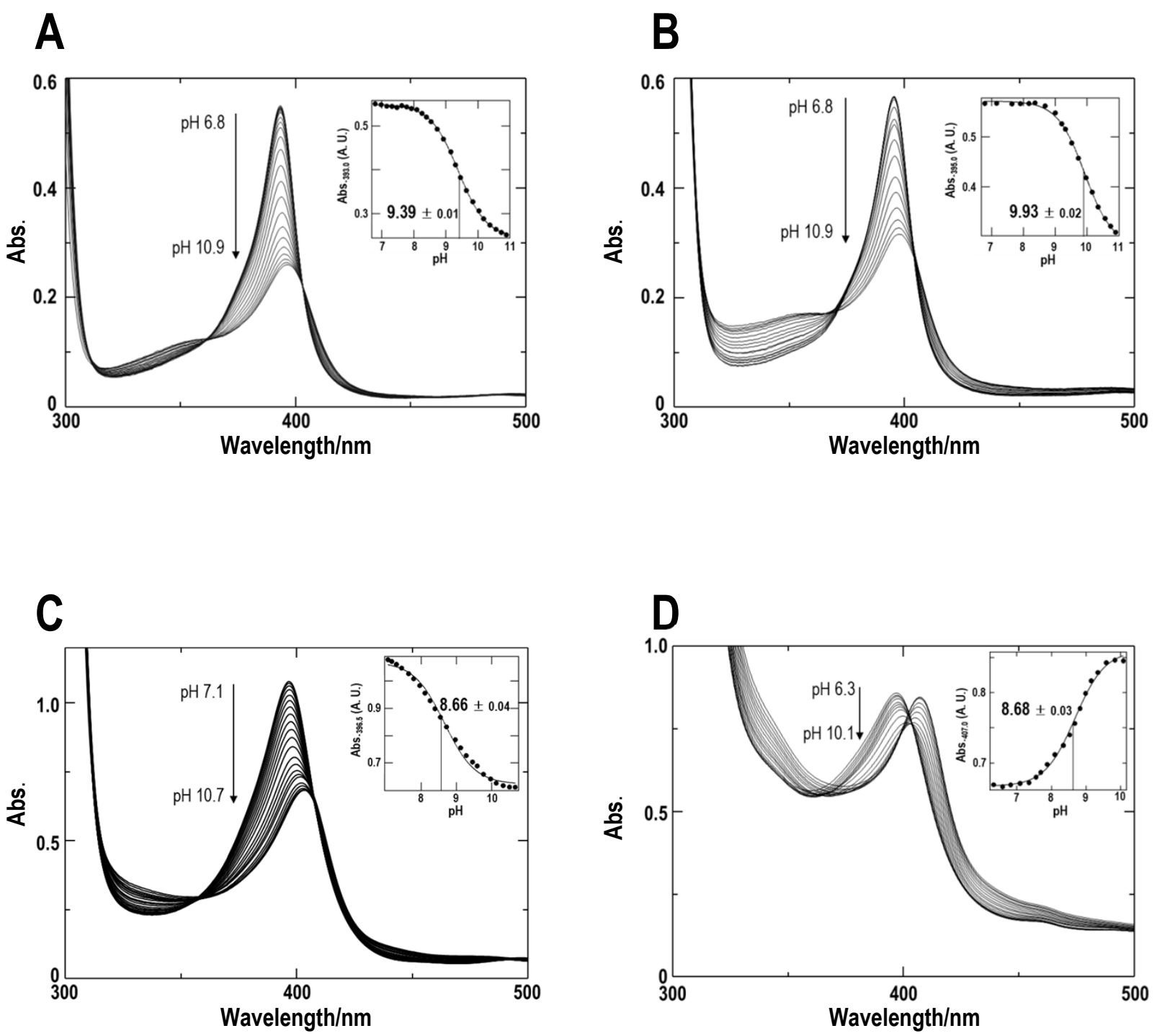

Figure S5. $\mathrm{pH}$ dependence of Soret absorption of the 3,8-DMD $\left(\mathrm{Fe}^{3+}\right)-6 \mathrm{mer} / \mathrm{T}(\mathrm{A}), 3,8-$ $\mathrm{DMD}\left(\mathrm{Fe}^{3+}\right)-6 \mathrm{mer} / \mathrm{A} \quad$ (B), 2,8-DPF $\left(\mathrm{Fe}^{3+}\right)-6 \mathrm{mer} / \mathrm{T} \quad$ (C), and 2,8-DPF( $\left.\mathrm{Fe}^{3+}\right)-6 \mathrm{mer} / \mathrm{A}$ complexes (D) in $300 \mathrm{mM} \mathrm{KCl}$ and $50 \mathrm{mM}$ potassium phosphate buffer at $25^{\circ} \mathrm{C}$. Fitting of the plots of the 393.0-, 395.0-, 396.5-, and 407.0-nm absorbance of the 3,8$\operatorname{DMD}\left(\mathrm{Fe}^{3+}\right)-6 \mathrm{mer} / \mathrm{T}, \quad 3,8-\mathrm{DMD}\left(\mathrm{Fe}^{3+}\right)-6 \mathrm{mer} / \mathrm{A}, \quad 2,8-\mathrm{DPF}\left(\mathrm{Fe}^{3+}\right)-6 \mathrm{mer} / \mathrm{T}$, and 2,8$\mathrm{DPF}\left(\mathrm{Fe}^{3+}\right)-6 \mathrm{mer} / \mathrm{A}$ complexes, respectively vs $\mathrm{pH}$, shown in the inset, yielded $\mathrm{p} K_{\mathrm{a}} \mathrm{s}$ of 9.39 $\pm 0.01,9.93 \pm 0.02,8.66 \pm 0.04$, and $8.68 \pm 0.03$, respectively. 

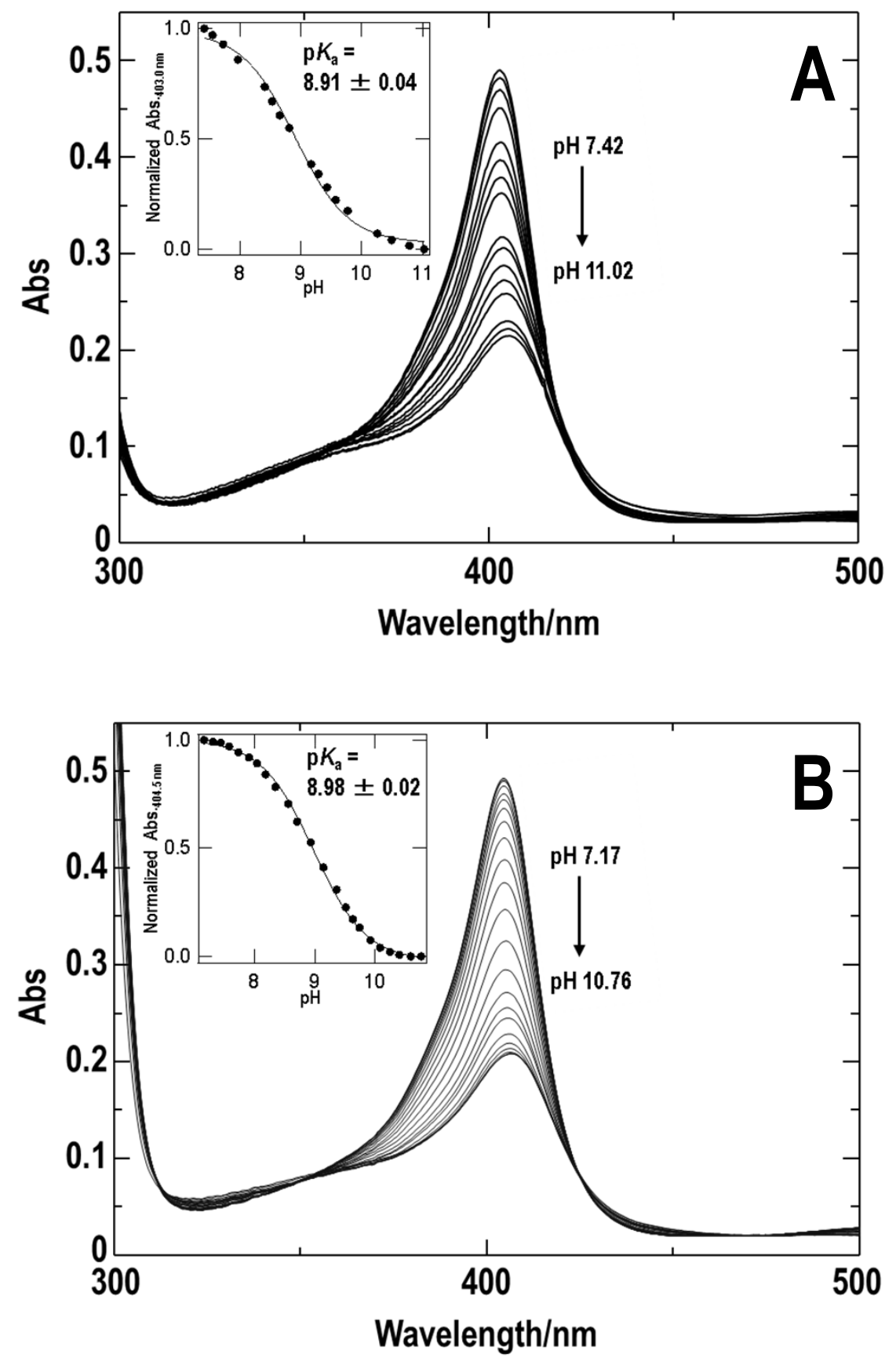

Figure S6. $\mathrm{pH}$ dependence of Soret absorption of the Proto $\left(\mathrm{Fe}^{3+}\right)-6 m e r(\mathrm{~A})$, and Proto $\left(\mathrm{Fe}^{3+}\right)-6 \mathrm{mer} / \mathrm{T}$ (B) complexes in $300 \mathrm{mM} \mathrm{KCl}$ and $50 \mathrm{mM}$ potassium phosphate buffer at $25{ }^{\circ} \mathrm{C}$. Fitting of the plots of the 403.0-, and 404.5-nm absorbance of the Proto $\left(\mathrm{Fe}^{3+}\right)-6$ mer, and Proto $\left(\mathrm{Fe}^{3+}\right)-6 \mathrm{mer} / \mathrm{T}$, complexes, respectively vs $\mathrm{pH}$, shown in the inset, yielded $\mathrm{p} K_{\mathrm{a}} \mathrm{s}$ of $8.91 \pm 0.04$, and $8.98 \pm 0.02$, respectively. 


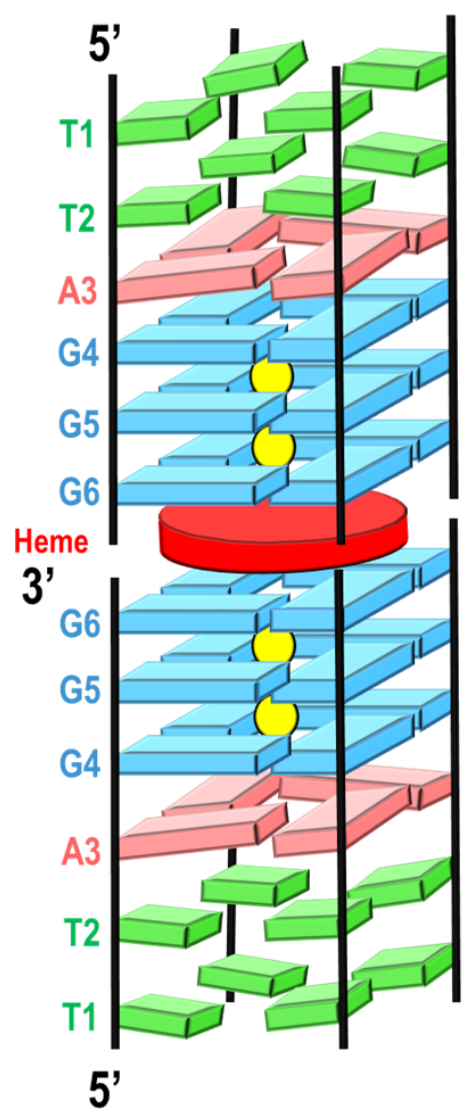

Figure S7. Schematic representation of the structure of the $1: 2$ heme $\left(\mathrm{Fe}^{3+}\right)$ 6mer complex. Heme $\left(\mathrm{Fe}^{3+}\right)$ is sandwiched between the 3'-terminal G-quartets of 6 mers (Saito, K., Tai, H., Hemmi, H., Kobayashi, N., and Yamamoto, Y. (2012) Inorg. Chem., 51, 8168-8176). 